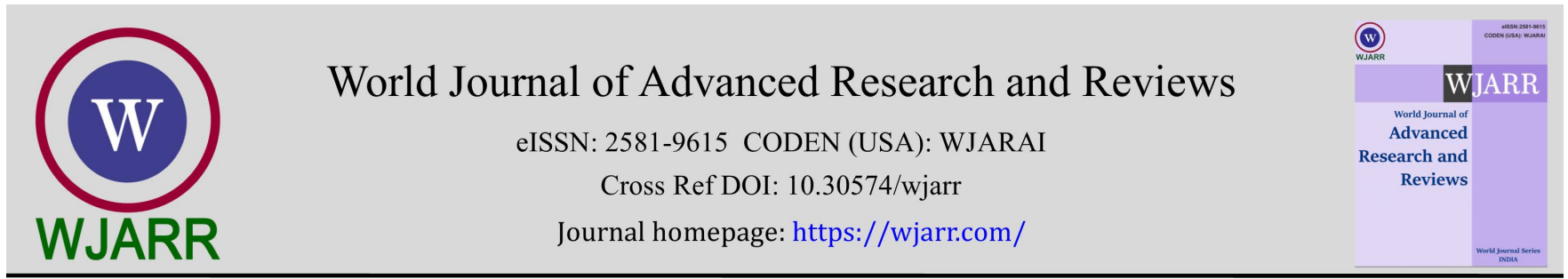

(RESEARCH ARTiCle)

\title{
Service room design for improving service quality of Utsman bin Affan library Universitas Muslim Indonesia with Kansei Engineering approach
}

\author{
Lamatinulu *, Muh. Syaeful Ragali, and Irma Nur Afiah \\ Department of Industrial Engineering, Faculty of Industrial Technology, Universitas Muslim Indonesia.
}

World Journal of Advanced Research and Reviews, 2021, 12(03), 381-392

Publication history: Received on 14 November 2021; revised on 18 December 2021; accepted on 20 December 2021

Article DOI: https://doi.org/10.30574/wjarr.2021.12.3.0707

\begin{abstract}
A student can study well if there is a good place to study as well. Likewise with reading, a person needs concentration to read. Service room design is necessitated in the reading room because it affects one's reading comfort. Utsman bin Affan library UMI Makassar is a place for students to study. Students' complaints and problems that are experienced when using the library service room are in the form of uncomfortable facilities, no closed rooms, and other complaints. In reference to these problems, a study was carried out in accordance with the students' complaints by employing Kansei Engineering approach. Kansei Engineering is a consumer-oriented ergonomic technology which enables the consumer's image or feeling to unite with the service design process of a product. By utilizing this method, product strategy and concept creation in the design of a product or service can be determined. The final results of Utsman bin Affan UMI Makassar library service room which was obtained based on the Kansei Engineering method are an open service room, large display, reading room, multimedia room, collection room, green and white colors, 3D motif and glossy texture. In addition to the main specifications of the library, there is also an additional item supporting the service room, which is a partition made of glass that gives the impression of being open to the room although it is still divided into different spaces.
\end{abstract}

Keywords: Kansei Engineering; Kansei Word; Service Design; Factor Analysis

\section{Introduction}

In facilitating education, there are many ways that we can do, one of which is reading more books in the library [1]. Information and communication technology-based libraries with library development are the demands of libraries in meeting the needs of the times. Libraries must have changed their physical form into non-physical or digital forms that can be accessed anywhere and anytime by the public. One thing that must be considered in the library is the reading room [2]. Performance measurement indicators for the customer perspective are required to measure library performance. Identification of performance indicators is an important factor in performance management because KPI (Key Performance Indicator) is a measure to periodically review the progress of an organization towards their goals and can be used to measure performance on an ongoing basis [3]. In this respect, a study will be conducted to develop a service room design at the Utsman bin Affan library that is in accordance with the complaints of students using Kansei Engineering approach. [4].

The complaints include seating comfort, table comfort, no closed room, and many others [5]. Therefore, facilities are demanded to support the continuity of the teaching and learning process such as study desks and study chairs. However, when writing activities are carried out using study desks and chairs, students tend to lean forward, bend down and dangle their feet. Ergonomic product evaluation must be adjusted to sequential use [6].

\footnotetext{
${ }^{*}$ Corresponding author: Lamatinulu

Department of Industrial Engineering, Faculty of Industrial Technology, Universitas Muslim Indonesia.

Copyright (C) 2021 Author(s) retain the copyright of this article. This article is published under the terms of the Creative Commons Attribution Liscense 4.0.
} 
In order to produce an optimal arrangement of library service spaces and to support the smooth functioning of the library as a service provider institution, librarians should pay attention to several aspects, which include functional aspects, psychological aspects, and aesthetic aspects [7]. In addition to the objectives of the library layout that must be achieved, it is also necessary to pay attention to spatial factors so that the arrangement and utilization of the spaces can be well organized, which cover the distance factor, the service space connection factor, and the service space utilization factor [8]. Basically, even the simplest library must have a number of rooms that have different functions. In other words, a library has a basic space, which is the minimum requirement of every library. Without space separation, the library will not be able to run properly. The minimum spaces that a library must have include a library building, collection room, reading room, staff room, and technical workspace. [8].

Since the establishment of Universitas Muslim Indonesia on June 23, 1954 as a private university, it has been under the coordination of Kopertis Region IX and Kopertis Region VIII. Universitas Muslim Indonesia is located on campus I Jalan Kakatua No. 27 Ujung Pandang. With the inauguration of the three-floor library building by the Director of Private Higher Education, Prof. Dr. Yuhara Sukra, the library was later given the name "Utsman Bin Affan Library, Universitas Muslim Indonesia." In 1994, UMI library utilized an automated computerized system with Sipisis program which aims to facilitate its service to the library users. In 2014, UMI Library implemented a new program as an automation system in the library, i.e., SLiMS (Senayan Library Management System) program, which was modified to suit the needs of the library. In the article entitled "Factors influencing users' satisfaction and loyalty to digital libraries in Chinese Universities", it was emphasized that a librarian must strengthen the communication (interaction) with users and manage user experience data as an evaluation material to improve service quality [9].

Kansei engineering refers to the expression of a product or circle, in which the emotions and images of the product have been stored in one's mind. For example, the expression that "the product is special" or "the product has a youthful style" is a Kansei Engineering impression in the form of an adjective, although it can also be a noun. In the field of design, Kansei is one of the most important elements that bring the will or power to create something [10].

One of the databases owned by Kansei Engineering is the Kansei database (Kansei word database). Kansei Words used in new product domain are collected from related system magazines. The products developed using Kansei Engineering or what commonly called Kansei products do not have to be expensive or have high technology because the desires and emotions of consumers are translated both in the form of functions and in the form of products. Kansei words are obtained from the results of a questionnaire [11]. For the service room design of the Ustman bin Affan library UMI Makassar, a software that can help and facilitate the validation of the implementation data is SPSS (Statistical Package for the Social Sciences) 25.0. SPSS (Statistical Package for the Social Sciences) 25.0 is a program that is used for processing statistical data on Kansei Word data from library users.

\section{Methodology}

\subsection{Time and Place of Research}

The research was carried out in September - November 2020 at Utsman bin Affan library of UMI Makassar at Campus II UMI Jl. Urip Sumoharjo KM 5 Makassar City, South Sulawesi Province.

\subsection{Data Processing}

The data processing in this research used Kansei Engineering type-I method or the method of determining a person's image which is translated into a product by:

- $\quad$ Identifying the target, i.e., for whom this product will be given. The target can be determined by several experts of a product or from the results of a marketing survey.

- $\quad$ Determining the product concept, which will be made for further development by observing the existing conditions or asking directly to those who will use the product.

- Dividing the product concept into several levels to identify the characteristics of a design that will be made. The characteristics of a product can be in the form of function, shape, and size.

- Mapping the physical design characteristics in the form of a tree diagram that has many branches at the bottom. At this step, the product characteristics start to be visible, for example light weight, easy to carry, and bright in color. 
- Translating the specifications, i.e., physical design characteristics into technical specifications. This step is useful to help users perform things easier with the product that is created.

\section{Results and discussion}

\subsection{Kansei words}

Table 1 Collection of Kansei Words

\begin{tabular}{|c|c|c|c|}
\hline No. & Kansei Words & No. & Kansei Words \\
\hline 1 & Comfortable & 74 & Minimalist \\
\hline 2 & Beautiful & 75 & Tranquil \\
\hline 3 & Natural & 76 & Colored \\
\hline 4 & Warm & 77 & Interesting \\
\hline 5 & Tranquil & 78 & Fragrant \\
\hline 6 & Minimalist & 79 & Bright \\
\hline 7 & Cool & 80 & Cool \\
\hline 8 & Accessible & 81 & Complete \\
\hline 9 & Comfortable & 82 & Cool \\
\hline 10 & Minimalist & 83 & Tranquil \\
\hline 11 & Bright & 84 & Safe \\
\hline 12 & Quiet & 85 & Comfortable \\
\hline 13 & Comfortable & 86 & Fragrant \\
\hline 14 & Clean & 87 & Tranquil \\
\hline 15 & Neat & 88 & Cool \\
\hline 16 & Elegant & 89 & No queue \\
\hline 17 & Organized & 90 & Accessible \\
\hline 18 & Neat & 91 & Pretty \\
\hline 19 & Cool & 92 & Comfortable \\
\hline 20 & Minimalist & 93 & Comfortable \\
\hline 21 & Comfortable & 94 & No student card \\
\hline 22 & Tranquil & 95 & Versatile \\
\hline 23 & Cool & 96 & Clean \\
\hline 24 & Bright & 97 & Neat \\
\hline 25 & Multifunctional & 98 & Tranquil \\
\hline 26 & Tranquil & 99 & Flexible \\
\hline 27 & Patterned & 100 & Cool \\
\hline 28 & Interesting & 101 & Magnificent \\
\hline 29 & Painting & 102 & Fragrant \\
\hline 30 & Tranquil & 103 & Comfortable \\
\hline 31 & Cold & 104 & Fragrant \\
\hline 32 & Comfortable & 105 & Comfortable \\
\hline 33 & Many rooms & 106 & Clean \\
\hline 34 & Warm & 107 & Fragrant \\
\hline 35 & Cool & 108 & Tranquil \\
\hline 36 & Gratis & 109 & Comfortable \\
\hline 37 & Tranquil & 110 & Cool \\
\hline & & & \\
\hline
\end{tabular}




\begin{tabular}{|c|c|c|c|}
\hline 38 & Lack of books & 111 & Gratis \\
\hline 39 & Comfortable & 112 & Natural feel \\
\hline 40 & Wide & 113 & Sunny \\
\hline 41 & Fresh & 114 & No queue \\
\hline 42 & Natural & 115 & Livelier \\
\hline 43 & Modern & 116 & Neat \\
\hline 44 & Tranquil & 117 & Clean \\
\hline 45 & Cool & 118 & Colored \\
\hline 46 & Complete literature & 119 & Renewable \\
\hline 47 & Comfortable & 120 & Elegant \\
\hline 48 & Multifunctional & 121 & Not much garbage \\
\hline 49 & Modern & 122 & Neat \\
\hline 50 & Tranquil & 123 & Lack of literature \\
\hline 51 & Clean & 124 & Queue \\
\hline 52 & Neat & 125 & Must use library card \\
\hline 53 & Cool & 126 & Fresh \\
\hline 54 & Tranquil & 127 & Interesting \\
\hline 55 & Friendly & 128 & Colorful \\
\hline 56 & Fragrant & 129 & Multifunctional \\
\hline 57 & Minimalist & 130 & Beautiful to see \\
\hline 58 & Free in and out & 131 & Open \\
\hline 59 & Insulated & 132 & Hot \\
\hline 60 & Not noisy & 133 & Informative \\
\hline 61 & Bright & 134 & Quiet \\
\hline 62 & Warm & 135 & Magnificent \\
\hline 63 & Clean & 136 & Resting place \\
\hline 64 & Clean & 137 & With ID card \\
\hline 65 & Comfortable & 138 & Livelier \\
\hline 66 & Cool & 139 & Neat \\
\hline 67 & Fragrant & 140 & Fast \\
\hline 68 & Simple & 141 & No queue \\
\hline 69 & Gratis & 142 & Hot \\
\hline 70 & With lamp & 143 & Must pay \\
\hline 71 & Cool & 144 & Informative \\
\hline 72 & Open & 145 & Colored \\
\hline 73 & With special room & 146 & Fragrant \\
\hline
\end{tabular}

The identification of Kansei words was carried out by distributing questionnaires to 60 respondents who had visited the Utsman bin Affan Library. Based on the questionnaires filled out by 60 subjects, 146 kansei words were obtained. Those one hundred and forty-six (146) kansei words obtained from respondents online were then selected by conducting a frequency test in which they will be grouped with the same repeated words. After that, the kansei words were eliminated by selecting the highest number of frequencies of Kansei words based on the selection of respondents. However, in this elimination stage, the researcher had the right to input the kansei word which was less chosen by the respondents, but was deemed more suitable for designing the service room design of the Utsman bin Affan Library. 
Table 2 Selected Kansei Words with the Same Meaning

\begin{tabular}{|c|l|}
\hline No & Selected Kansei Words with the Same Meaning \\
\hline 1 & Comfortable \\
\hline 2 & Tranquil \\
\hline 3 & Multifunctional \\
\hline 4 & Cold \\
\hline 5 & Bright \\
\hline 6 & Neat \\
\hline 7 & Colored \\
\hline 8 & Magnificent \\
\hline 9 & Natural \\
\hline 10 & Livelier \\
\hline 11 & Free \\
\hline 12 & Beautiful \\
\hline
\end{tabular}

One of the databases owned by Kansei Engineering is the Kansei database (Kansei word database). Kansei Words used in the new product domain are collected from the related system magazines.

Table 3 Kansei Word Pairs

\begin{tabular}{|c|l|l|}
\hline No & \multicolumn{2}{|c|}{ Opposite Kansei Words } \\
\hline 1 & Comfortable & Uncomfortable \\
\hline 2 & Tranquil & Noisy \\
\hline 3 & Multifunctional & Monofunctional \\
\hline 4 & Cold & Hot \\
\hline 5 & Bright & Dark \\
\hline 6 & Neat & Messy \\
\hline 7 & Colored & Plain \\
\hline 8 & Magnificent & Simple \\
\hline 9 & Natural & Artificial \\
\hline 10 & Livelier & Boring \\
\hline 11 & Free & Not free \\
\hline 12 & Beautiful & Common \\
\hline
\end{tabular}

After collecting the Kansei words obtained based on field observations and interviews, the next step was making Semantic Differential I which was used as a Kansei questionnaire and then implemented into product design. 
Table 4 Semantic Differential Questionnaire

\begin{tabular}{|l|l|l|l|l|l|l|l|l|}
\hline \multirow{2}{*}{ Words } & \multicolumn{6}{|c|}{ Differential Semantic Scale } & \multirow{2}{*}{ Words } \\
\cline { 2 - 7 } & 1 & 2 & 3 & 4 & 5 & 6 & 7 & \\
\hline Comfortable & & & & & & & & Uncomfortable \\
\hline Tranquil & & & & & & & & Noisy \\
\hline Multifunctional & & & & & & & & Monofunctional \\
\hline Cold & & & & & & & & Hot \\
\hline Bright & & & & & & & & Dark \\
\hline Neat & & & & & & & & Messy \\
\hline Colored & & & & & & & & Plain \\
\hline Magnificent & & & & & & & Simple \\
\hline Natural & & & & & & & & Artificial \\
\hline Livelier & & & & & & & & Boring \\
\hline Free & & & & & & & & Not free \\
\hline Beautiful & & & & & & & & Common \\
\hline
\end{tabular}

Semantic differential data collection was carried out in 2 stages, i.e., semantic differential I data collection and semantic differential data collection II. The first semantic differential data collection was carried out to test Kansei words by means of validity and reliability tests. Meanwhile, the second semantic differential data collection was carried out to select the product designs based on conjoint analysis and factor analysis.

\subsection{Validity and Reliability Tests}

The data is declared valid if the kansei word tested in the questionnaire can describe the product image. The data processing was caried out by using SPSS 25.0 software.

Table 5 First Validation Test

\begin{tabular}{|c|l|c|c|}
\hline No & Kansei Words & Value & Note \\
\hline 1 & Comfortable & 0.748 & Valid \\
\hline 2 & Tranquil & 0.647 & Valid \\
\hline 3 & Multifunctional & 0.602 & Valid \\
\hline 4 & Cold & 0.665 & Valid \\
\hline 5 & Bright & 0.776 & Valid \\
\hline 6 & Neat & 0.810 & Valid \\
\hline 7 & Colored & 0.635 & Valid \\
\hline 8 & Magnificent & 0.652 & Valid \\
\hline 9 & Natural & -0.089 & Not Valid \\
\hline 10 & Free & 0.757 & Valid \\
\hline
\end{tabular}

In the first validation test stage, 1 kansei word which was declared invalid was then removed. The other 11 kansei words that were previously declared valid were then tested for their validity again. 
Table 6 Second Validation Test

\begin{tabular}{|l|l|l|l|}
\hline No & Kansei Words & Value & Note \\
\hline 1 & Comfortable & 0.743 & Valid \\
\hline 2 & Tranquil & 0.646 & Valid \\
\hline 3 & Multifunctional & 0.587 & Valid \\
\hline 4 & Cold & 0.657 & Valid \\
\hline 5 & Bright & 0.790 & Valid \\
\hline 6 & Neat & 0.832 & Valid \\
\hline 7 & Colored & 0.663 & Valid \\
\hline 8 & Magnificent & 0.679 & Valid \\
\hline 9 & Free & 0.762 & Valid \\
\hline 10 & Livelier & 0.486 & Valid \\
\hline 11 & Beautiful & 0.592 & Valid \\
\hline
\end{tabular}

The results of the second validity analysis above show that the 11 selected kansei words have met the validity standard, which was $>0.30$. This shows that the 11 kansei words have uniformity of data and can be used in this study. The next stage was reliability analysis to see the adequacy of research data.

Table 7 Reliability Test Result

\begin{tabular}{|c|c|}
\hline \multicolumn{2}{|c|}{ Reliability Statistics } \\
\hline Cronbach's Alpha & N of Items \\
\hline 0.879 & 11 \\
\hline
\end{tabular}

The result of the reliability test showed the Cronbach's Alpha value of 0.879 which means that this data is reliable because it was $>0.7$.

Before carrying out further data processing, the data first had to be checked to determine the adequacy of the data. Knowing whether the data is sufficient or not can be carried out through the data adequacy test. The data is considered sufficient if the result of the adequacy test shows $\mathrm{N}^{\prime}<\mathrm{N}$. If the data is sufficient, then there is no need to add other data anymore. However, if the result of the data adequacy test is $\mathrm{N}^{\prime}>\mathrm{N}$, it means that the data is not sufficient. In ord er for the data to be sufficient, additional data are added because the existing data are not sufficient to be used as a population sample.

Based on the data processing above, the result showed that N' was 28.09. Therefore, the data is declared sufficient because the value of $N^{\prime}(28.09)<N(60)$.

\subsection{Kansei Words Based on KBBI (The Great Dictionary of the Indonesian Language)}

Table 8 Kansei Words Based on KBBI

\begin{tabular}{|c|l|l|}
\hline No & Kansei Words & Definition \\
\hline 1 & Comfortable & Fresh, healthy, pleasant, cool, good \\
\hline 2 & Tranquil & Not nervous, not anxious, not messy, not noisy, safe and calm (feeling, situation) \\
\hline 3 & Multifunctional & Having many tasks/functions \\
\hline 4 & Cold & Low temperature, not hot, cool \\
\hline 5 & Bright & Emitting light, shining (lamp, sun) \\
\hline
\end{tabular}




\begin{tabular}{|c|l|l|}
\hline 6 & Neat & Good, organized, clean, nice \\
\hline 7 & Colored & Impression to eyes from light, pattern \\
\hline 8 & Magnificent & Impressive (because of the hugeness or beauty) \\
\hline 9 & Free & Not disturbed, can move, do, etc. \\
\hline 10 & Livelier & Still existing, moving, and working as it should \\
\hline 11 & Beautiful & Nice to see, pretty, lovely \\
\hline
\end{tabular}

\subsection{Initial Design}

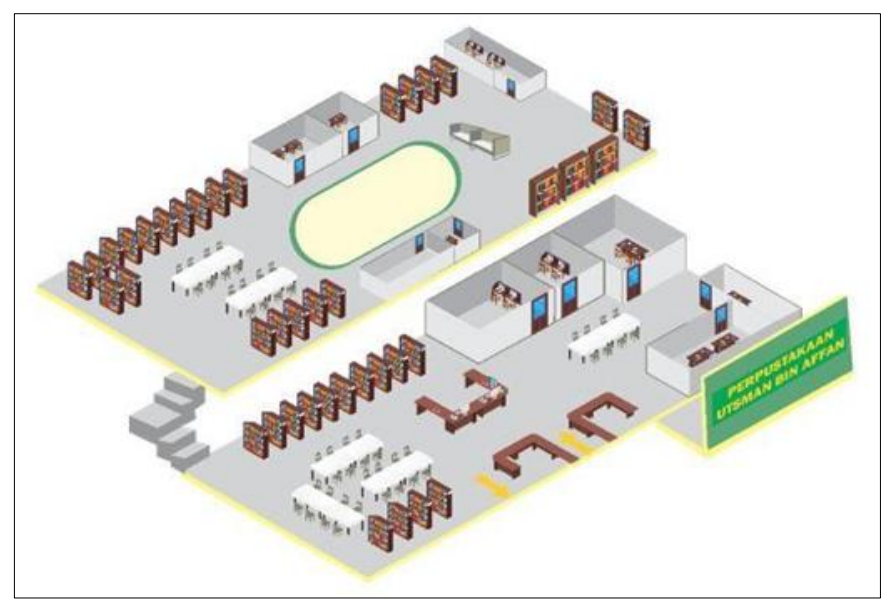

Figure 1 Initial Layout of the Library

Table 9 Area of space required

\begin{tabular}{|l|c|}
\hline Number of Students & Space Area (m2) \\
\hline$+1,000$ & 200 \\
\hline $1,000-2,500$ & 500 \\
\hline $2,501-5,000$ & 1,000 \\
\hline $5,001-7,500$ & 1,500 \\
\hline $7,501-10,000$ & 2,000 \\
\hline $10,001-20,000$ & 4,000 \\
\hline
\end{tabular}

The number of Indonesian Muslim University Campus II students for the 2020/2021 academic year was 4500 students (berita umi.ac.id).

\subsection{Rooms}

The library room is based on national library standards, which are:

- $\quad$ Collection Area (information literacy, writings, journals, etc.) $45 \%$

- User Collection Area (reading and studying) 25\%

- Work Areas (administration, circulation services) $10 \%$

- $\quad$ Other Areas (discussion area, creative activity area, etc.) $20 \%$ 


\subsection{Items and Categories}

The determination of items and categories served to form a combination of product samples that were used in the Semantic Differential II questionnaire. There were several processes in determining the formation of product designs in this study, i.e., by using the morphological chart method.

Table 10 Initial Layout of the Library

\begin{tabular}{|c|c|c|c|}
\hline \multicolumn{4}{|r|}{ Items and Categories } \\
\hline No & Item & No & Category \\
\hline \multirow{2}{*}{1} & \multirow{2}{*}{ Shape } & 1 & Opened \\
\hline & & 2 & Closed \\
\hline \multirow{2}{*}{2} & \multirow{2}{*}{ Appearance } & 1 & Big \\
\hline & & 2 & Small \\
\hline \multirow{3}{*}{3} & \multirow{3}{*}{ Rooms } & 1 & Reading room, resting room, collection room \\
\hline & & 2 & Reading room, multimedia room, collection room \\
\hline & & 3 & Reading room, discussion room, collection room \\
\hline \multirow{2}{*}{4} & \multirow{2}{*}{ Colors } & 1 & Dark green and white \\
\hline & & 2 & Yellow and white \\
\hline \multirow{2}{*}{5} & \multirow{2}{*}{ Motifs } & 1 & 3 Dimension \\
\hline & & 2 & 2 Dimension \\
\hline \multirow{2}{*}{6} & \multirow{2}{*}{ Texture } & 1 & Glossy \\
\hline & & 2 & Soft \\
\hline
\end{tabular}

The determination of combinations and stimuli was carried out on each design element that had been grouped. The aim was to provide an assessment of the suitability or relationship between designs that had been formed in the combination of stimuli. The determination of the combination of these design elements utilized orthogonal design in the latest SPSS 25.0 software.

The product samples given to the respondents were 16 samples. The product samples were displayed in the form of images that were suitable with the specifications of each sample. The second questionnaire also used 7-point Semantic scale with the same order as the first questionnaire.

\subsection{Proposed Space Design}

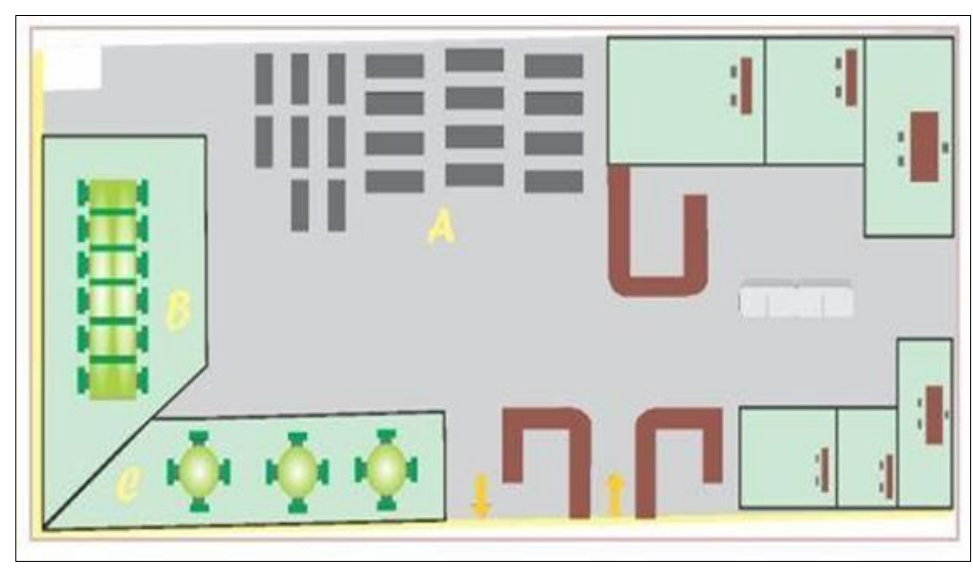

Figure 2 First Floor Room Design

According to the picture above, then the concept obtained was to make a service room design with a total of 3 rooms based on the expectation of students and visitors. 


\subsection{Space Design Specifications}

The library reading space is designed in a room with a composition of $25 \%$.

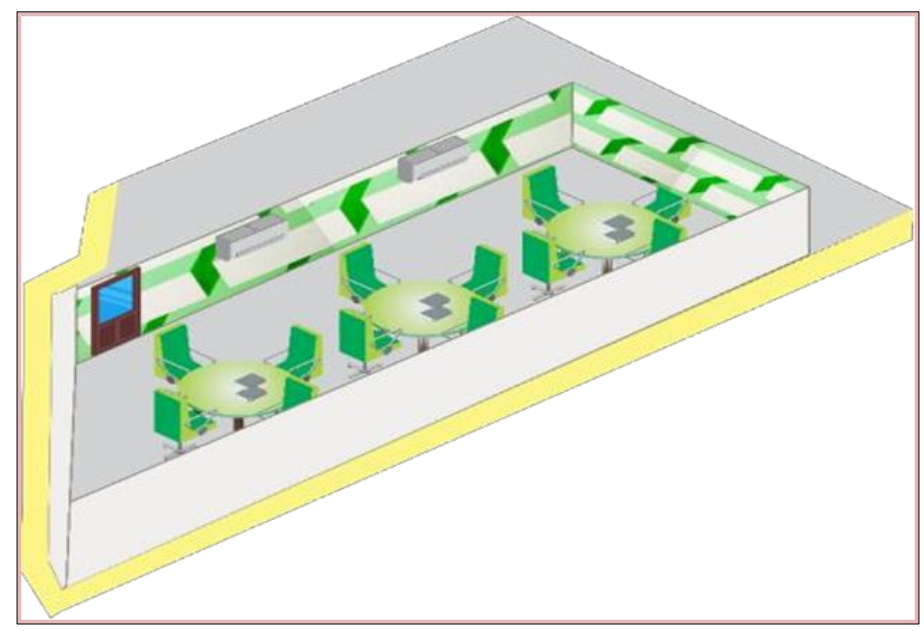

Figure 3 Reading Room

The multimedia room that supports the learning process is designed with a composition of $20 \%$.

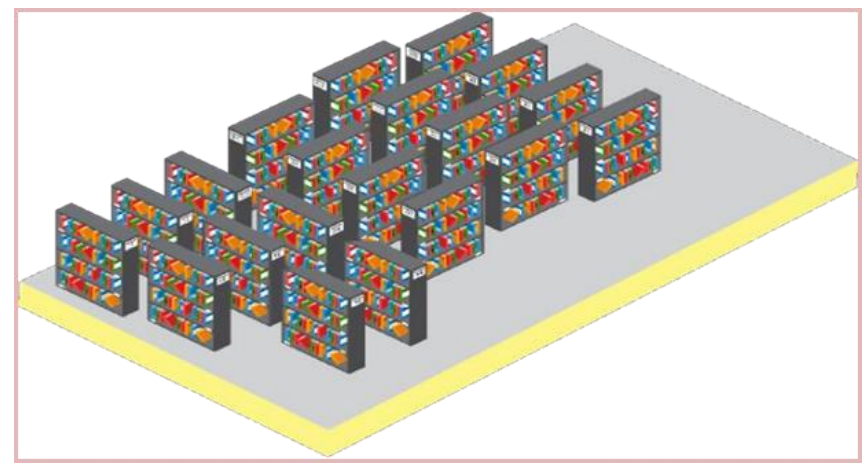

Figure 4 Collection Room

Library material collection room that has been managed with a composition of $45 \%$.

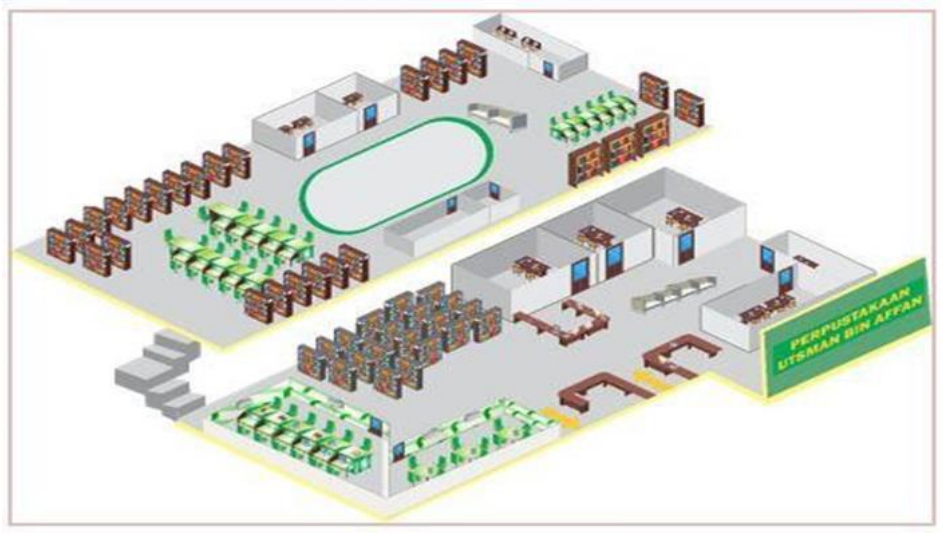

Figure 5 Overall Design

The design specifications are based on conjoint analysis of the open-shaped design of the building with a large display in the room. In addition, the room has 3 rooms (reading, multimedia and collections) with green color combined with white and 3D motifs. Therefore, the impression is livelier and the added glossy texture gives shiny and bright effect. 


\section{Conclusion}

- Based on the results of the identification of Kansei words, the expectation of students or visitors to the Utsman bin Affan library service room are comfortable (0.743), quiet (0.743), multifunctional (0.587), cold (0.657), bright (0.790), neat (0.832), colorful (0.663), magnificent (0.679), free (0.762), livelier (0.486), and beautiful (0.592).

- $\quad$ Based on the results of the Kansei engineering analysis, the shape design for the chair is to have a height of 45 $\mathrm{cm}$, a width of $45 \mathrm{~cm}$ and a depth of $45 \mathrm{~cm}$, for the typing table is to have a height of $75 \mathrm{~cm}$, a width of $230 \mathrm{~cm}$ and a depth of $100 \mathrm{~cm}$, for the reading table is to have a height of $75 \mathrm{~cm}$, a width of $100 \mathrm{~cm}$ and a depth of 50 $\mathrm{cm}$, and for collection shelves is to have a height of $130 \mathrm{~cm}$, a width of $100 \mathrm{~cm}$, a depth of $20-21 \mathrm{~cm}$ and a thickness of $2 \mathrm{~cm}$. The service room, which consists of $25 \%$ reading room, $20 \%$ multimedia room and $45 \%$ collection room, has specific colors with a combination of green and white, 3 dimensional patterned walls, and glossy (shiny) color texture.

\section{Recommendations}

- It is expected that the library management can better understand the needs of students or library visitors on the service room side in order to improve the quality of service. It is also expected that the library management can use the service room design that has been proposed in this study.

- Students, visitors and readers are expected to maintain the room and use it according to their needs to maintain cleanliness and tidiness. It is expected that the next research regarding the application of Kansei engineering method can add other supporting methods for the perfection of the research and find more sources.

\section{Compliance with ethical standards}

\section{Acknowledgments}

The authors would like to thank the central library of the Muslim University of Indonesia and all those who provided assistance in supporting the smooth running of this research.

\section{Disclosure of conflict of interest}

All authors in the making of this scientific article have no conflict of interest.

\section{References}

[1] BSNP. Design of Higher Education Standards and Infrastructure for Undergraduate and Professional Programs. 2011.

[2] Lantara D, Nusran M. The Industrial World: Labor Psychology Perspectives. Makassar; Nas Media Pustaka. 2019.

[3] Haryanto H. Optimizing Higher Education Library Services through the Utilization of Social Media Networking as a Communication Media Between Libraries and Users. Jurnal Pustaka Ilmiah. 2015; 1(1): 39 - 45.

[4] Afiah IN, Dahlan M. Ahmad A, Sakti AY. Ergonomic Evaluation Of Study Desks And Chairs Usinganthropometry And Biomechanical Approach At An-Nuriyahislamic Boarding School Bontocini Jeneponto Regency. Journal of Industrial Engineering Management. 2020; 5(2): 31 - 42.

[5] Kim SK, Cho Y, Niki K, Yamanaka T. The Relationship between Preference and Kansei Values. International Conference on Biometrics and Kansei Engineering. 2012; 11(4): 259 - 266.

[6] Lamatinulu M., Dahlan, Ramlawati. Identification and Determination of the Priority of Key Performance Indicators Perspective of Customers on Industry of Smes Scale in South Sulawesi. International Journal of Engineering Sciences \& Research Technology. 2018; 7(7): 41 - 47.

[7] Nagamachi and Lokman. Innovation of Kansei Engineering. CRC Press. Indeks. 2011. 
[8] Wakhid AG. The Development of a Wheelchair Design Especially for the Elderly Based on a Product Image Using the Kansei Engineering Method. Thesis Faculty of Engineering, Industrial Engineering, Sebelas Maret University. 2011.

[9] Yi YS, Ibrahim AAA, Bolongkikit J. Incorporating Kansei Engineering into Sound Design to Improve Sonification. Australian Journal of Basic and Applied Science. 2015; 9(32): 133 - 137.

[10] Putra GS, Martini S, Iqbal M. Design Supermarket Trolley Using Implementation Kansei Engineering Method. eProceeding of Engineering. 2017; 4(2): 2453-2459.

[11] Xu F, Du JT. Factors influencing users' satisfaction and loyalty to digital libraries in Chinese universities. Computers in Human Behavior. 2018; 83: 64-72. 